\title{
1 Steam explosion pretreatment of willow grown on phytomanaged soils for
}

\section{2 bioethanol production}

3 Authors : Isabelle Ziegler-Devin ${ }^{\mathrm{a}}$, Zahra Menana ${ }^{\mathrm{a}}$, Laurent Chrusciel ${ }^{\mathrm{a}}$, Michel Chalot ${ }^{\mathrm{b}, \mathrm{c}}$,

$4 \quad$ Valérie Bert ${ }^{\mathrm{d}}$, Nicolas Brosse $\mathrm{a}^{\mathrm{a}^{*}}$

5 Affiliations:

$6 \quad{ }^{a}$ Laboratoire d'Etude et de Recherche sur le MAteriau Bois, Faculté des Sciences et

7 Technologies, Université de Lorraine, Bld des Aiguillettes, F-54500 Vandoeuvre-lès-Nancy,

8 France

9 baboratoire Chrono-Environnement, UMR CNRS 6249, Université de Bourgogne

10 Franche-Comté, Montbéliard, France

$11{ }^{\mathrm{c}}$ Université de Lorraine, Faculté des Sciences et Technologies, Vandœuvre-les-Nancy,

12 France

13 d Unité Technologies et Procédés Propres et Durables, INERIS, Parc technologique Alata,

14 BP2, 60550 Verneuil en Halatte, France

$15 *$ Corresponding author. E-mail address: Nicolas.Brosse@ univ-lorraine.fr ; tel +33372745626 
1 Abstract

2 A steam explosion (SE) process was evaluated as a pretreatment method to achieve

3 simultaneously the pretreatment and the decontamination of trace elements (TE) from woody

4 biomass for bioethanol applications. The willow biomass used in this study was obtained from

5 short rotation coppice phyto-managed plots harvested on a TE-contaminated soils ( $\mathrm{Zn}, \mathrm{Mn})$.

6 The influence of the SE reaction severity on the composition of the cellulosic pulp and on the

7 TE extraction in the water effluent was investigated. SE performed at $220^{\circ} \mathrm{C}$ after a $2 \%$

8 sulfuric acid presoaking allowed an extraction of $\sim 80 \%$ of $\mathrm{Mn}$ and $\mathrm{Zn}$ in the water effluent.

9 The enzymatic hydrolysis of the resulting pulps was examined. A cellulose-to-glucose conversion of $\sim 80 \%$ was obtained after $75 \mathrm{hr}$ of incubation of the pulp obtained after a SE treatment performed at $180{ }^{\circ} \mathrm{C}$. The subsequent fermentation into ethanol using

12 Saccharomyces cerevisiae was successfully performed. No significant influence of TEs on the 13 action of the biocatalysts (enzymes and yeast) was observed.

Key words : phytoremediation-borne biomass ; steam explosion ; bioethanol ; willow short rotation coppice ; trace element 
1. Introduction

Soil pollution due to human activities is a world-wide issue with significant environmental impact and health risks (Gallego et al., 2015, Nagendran et al., 2006, Medina et al., 2015). The presence of trace elements (TE) in high concentrations has been identified as one of the major threats to European soils. Recently, the utilization of plants and trees for the management of polluted land gained interest (Chalot et al., 2012, Suer and Andersson-Skold, 2011, Witters et al., 2012). These phytotechnologies include plant phytoextraction using crops with TE extraction capacity or phytostabilization in order to limit TE dissemination (Gomez, 2012). As a consequence, a subsequent utilization of the TE-enriched biomass seems to be suitable in order to limit the pollutant dissemination in the environment. It has been demonstrated from willow wood that a direct disposal of phytoextraction crops is associated with a high leachability of toxic TE (primarily $\mathrm{Zn}$ and $\mathrm{Cd}$ ) and thus a high probability of return to the environment (Syc et al., 2012).

In this context, the utilization of contaminated land for growing industrial crops could be a promising approach not only for polluted land management but also for biomass production (Gomez, 2012). Willow (Salix) has been described to be a promising phytoremediation crop for TE extraction because of its capacity to accumulate in aboveground biomass compartments relatively high levels of TE such as $\mathrm{Zn}$ (up to $\left.\sim 1000 \mathrm{mg} \cdot \mathrm{kg}^{-1}\right)$ and $\mathrm{Cd}(\sim 30$ mg.kg ${ }^{-1}$ ) (Syc et al., 2012, Migeon et al., 2009, Xu et al., 2018). The potential of Very Short Rotation Coppice (VSRC) of willow has been investigated for phytoremediation. The repeating harvesting of biomass (every 3-5 years) has been described to maximize the biomass production and to progressively reduce the TE content in the soil (Xu et al., 2015). Phytoremediation willow has been proposed as a potential source of biomass for bioenergy and various energy-recovery techniques such as combustion, gasification and pyrolysis (Migeon et al., 2009, Vervaeke et al., 2006, Delplanque et al., 2013). The mobilization of 
1 phytoremediation willow VSRC could be profitable for the production of biofuels in order to

2 reduce the impacts on the food markets. However, some important questions about the fate of

3 the TE during the process and their content in biofuel have to be addressed.

4 In a recent paper, we described the pretreatment of TE-enriched woody (Salix viminalis) and

5 non-woody biomass (Nicotiana tabacum L.) using dilute acid, alkali catalyzed and organosolv

6 pretreatments for the production of bioethanol and biofuel (Asad et al., 2017). The

7 distribution of TE in the pretreatment fractions (pulp, liquid effluent and lignin) was investigated. It was concluded that (1) the TE extractability was low in basic conditions, (2) using a dilute acid treatment TE were mainly recovered in the liquid effluent producing a clear pulp, (3) in organosolv treatment, TE extraction in liquid phase increased with the water content and the acidity but decreased with the temperature.

Steam explosion (SE) process is one of the most valuable and cost effective pretreatment technologies for cellulosic bioethanol production (Jacquet et al., 2015). This technology is currently developed at a commercial scale. During SE, biomass is treated with hot steam for short residence times ( 2-30 $\mathrm{min})$ at temperatures in the range of 180 to $210{ }^{\circ} \mathrm{C}$, followed by explosive decompression. The effect of SE on biomass combines a chemical hydrolysis, a thermal effect during the steam treatment and a mechanical effect during the explosive decompression. SE induces (1) a partial breakdown of glucosidic and lignin-hemicelluloses linkages by hydrolysis and of intramolecular hydrogen bonds (2) a thermo-mechanical defibration due to the flash evaporation of water in the cell wall (Jacquet et al., 2015, Sauvageon et al., 2018). As a result, SE is described as an efficient way to decrease the particle size and to induce an extensive defibration of the biomass. This process has been the subject of many studies for decades for increasing the accessibility of carbohydrates to enzymes but to the best of our knowledge, the SE pretreatment of TE-contaminated biomass produced on phytomanaged sites has never been examined. The aim of this study was to 
1 explore the potential of SE pretreatment of SRC willow biomass produced at TE-

2

contaminated and phytomanaged sites, for the production of bioethanol with a sound management of TE to avoid their dissemination in the environment. The influence of the severity of the SE process on the composition in TE of the cellulosic residues was examined.

The residual TE effect on the enzymatic hydrolysis of cellulose into glucose and on the fermentation step was also investigated.

\section{Materials and methods}

EtOH, $\mathrm{H}_{2} \mathrm{SO}_{4}, \mathrm{HNO}_{3}$ and $\mathrm{H}_{2} \mathrm{O}_{2}$ used in this study were purchased from Sigma Aldrich and used as received. The enzymes were obtained from Sigma Aldrich (St. Louis, MO).

\subsection{Plants materials}

Willow (Salix viminalis $\mathrm{W}$ ) was harvested on a TE-contaminated sediment disposal site located at Deûlémont (France) at an experimental plot described previously (Kidd et al., 2015). Because of their young age, willow samples contain bark. Willow stems with bark (stem diameter 1-3 cm) were milled to a powder using a Wiley mill and dried for 2-3 days at $40{ }^{\circ} \mathrm{C}$

\subsection{Steam explosion pretreatment}

Biomass was first impregnated during $15 \mathrm{hr}$ at room temperature with a $0.9 \%$ or $2 \%(\mathrm{w} / \mathrm{w}$ based on wood dry matter content) dilute sulfuric acid solution (water/biomass ratio : 15/1). After pressing, the biomass was transferred into a $2 \mathrm{~L}$ pressure-resistant steam gun where $50 \mathrm{~g}$ (dry basis) of biomass were exposed to steam at varying temperatures and residence times (see Table 2 for experimental conditions, the framework of the steam explosion facility has been described in a previous publication, Simangunsong et al., 2018). After the residence 
1 time, a pneumatic valve was open leading to the vapor phase exit from the reactor through a

2 nozzle entraining the biomass. Both liquid (SE water effluent) and solid (pulp) fractions are

3 then collected after SE pretreatment in the discharge tank. The severity factor, as shown in Eq.

4 (1), describes the severity of the pretreatment as a function of residence time (min) and

5 temperature $\left({ }^{\circ} \mathrm{C}\right)$ (Jacquet et al., 2015). The severity factor can be extended to facilitate

6 trading off among temperature, time, and acid concentration, using Eq. (1) (Chum et al.

7 1990). Severity factor and combined severity factor values for this study are grouped in Table 82

$\log R_{0}=\log \left(t \exp \frac{(T-100)}{14,75}\right)$

Where $\log \mathrm{R}_{0}$ : severity factor, $\mathrm{t}:$ residence time $(\mathrm{min}), \mathrm{T}:$ reaction temperature $\left({ }^{\circ} \mathrm{C}\right)$

\section{Equation 2}

$\log C_{s}=\log R_{0}-p H$

Where $\log \mathrm{C}_{\mathrm{s}}$ : combined severity factor, $\log \mathrm{R}_{0}$ : severity factor, $\mathrm{pH}: \mathrm{pH}$ measurement of the acidic pretreated hydrolysate

\subsection{TE analysis}

SE pretreated willow pulps were dried overnight at $105^{\circ} \mathrm{C}$ and then weighted aliquots $(0.2 \mathrm{~g}$ dry mass) were placed in a $50 \mathrm{~cm}^{3}$ Erlenmeyer flask respectively. Then $10 \mathrm{~cm}^{3}$ of nitric acid $(65 \%)$ were added in the flask and placed on a graphite bed at $85^{\circ} \mathrm{C}$. The flask was heated until reddish-brown fumes no more and then $4 \mathrm{~cm}^{3}$ of hydrogen peroxide was added dropwise. If some plant particles remained in the solution, an additional $4 \mathrm{~cm}^{3}$ hydrogen peroxide was added for total dissolution of material. After cooling, the solution adjusted to $200 \mathrm{~cm}^{3}$ with distilled water. TE content was determined by Inductively Coupled Plasma- 
1 Atomic Emission Spectrometry (ICP-AES, Radial ICAP 6500 Model, Thermo Fischer

2 Scientific, Courtaboeuf, France), and all samples were analyzed in triplicate with certified reference materials (INCT-OBTL-5, LGC Promochem, Molsheim, France). The recovered percentages of $\mathrm{Zn}$ and $\mathrm{Mn}$ concentrations in the treated material were calculated based on the initial concentration of TEs in biomass.

\subsection{Klason lignin and sugars analysis}

Extractive-free samples were ground and their moisture content was measured (Kern MRS 120-3 moisture analyzer). Approximately $0.175 \mathrm{~g}$ (exactly weighed) of dried samples was added to centrifuge tubes $\left(50 \mathrm{~cm}^{3}\right.$ tubes from Corning $\left.®\right)$ to which $1.5 \mathrm{~cm}^{3}$ of sulfuric acid (72 $\%)$ were added. The mixture was stirred few times with a glass rod and placed in a water bath at $30^{\circ} \mathrm{C}$ for $1 \mathrm{hr}$. After adding $42 \mathrm{~cm}^{3}$ of water, the tubes were autoclaved at $121{ }^{\circ} \mathrm{C}$ for $1 \mathrm{hr}$. The samples were then cooled and filtered with glass microfibers (particle retention $1.2 \mu \mathrm{m}$ ). The insoluble residue was washed with pure water, oven-dried at $105^{\circ} \mathrm{C}$ and weighed. Monosaccharide contents of the soluble fraction were analyzed by HAPE-PAD (ICS-3000 Dionex) equipped with a Dionex CarboPac ${ }^{\mathrm{TM}}$ PA-20 (3 x $\left.150 \mathrm{~mm}\right)$ analytical column using a described method (Asad et al., 2017).

\subsection{Enzymatic hydrolysis}

Enzymatic hydrolysis was performed on willow SE cellulosic pulp using standard literature conditions (Pan, 2008). The cellulosic pulp (1.0 g) was mixed with $50 \mathrm{~cm}^{3}$ of $50 \mathrm{mM}$ acetate buffer ( $\mathrm{pH} 4.8$ ) in a $100 \mathrm{~cm}^{3}$ Erlenmeyer flask and then incubated by shaking for $30 \mathrm{~min}$. After this preincubation step, the hydrolysis was initiated by adding 0.8 g. $\mathrm{L}^{-1}$ of cellulase (Trichoderma reesei) and prolonged by shaking $\left(175 \mathrm{rpm}\right.$ ) at $40{ }^{\circ} \mathrm{C}$ for $30 \mathrm{hr}$. The glucose contents of the aqueous phase were quantified using a Shimadzu High Performance Liquid Chromatograph (HPLC), equipped with an evaporative light scattering (ELS) detector and a 
1 Prevail Carbohydrates ES column. Acetonitrile/water $(75 \%, \mathrm{v} / \mathrm{v})$ was used as the eluent.

2 Enzymatic hydrolysis data were reported as averages from duplicate experiments.

3

4

5

\subsection{Fermentation tests}

The aqueous phases from the enzymatic hydrolysis experiments were fermented using Bakers' yeast (Saccharomyces cerevisiae). The method outlined in Söderstrom et al. (Söderstroem et al., 2003) has been followed for these experiments.

\subsection{Detoxification of SE water effluents}

Phosphorylated kraft fibers are brought into contact with SE water effluent $(0.1 \mathrm{w} / \mathrm{w})$ at room temperature for $1 \mathrm{hr}$ under stirring. TE content of the liquid effluent is measured before and after detoxification.

\section{Results and discussion}

The chemical composition of the willow samples, containing bark, examined in this study is given in Table 1. Compared to literature reports on the composition of willow wood, willow samples have a substantially lower polysaccharides content $(-60 \%)$ but significant amounts of galactan and galacturonan $(2.06 \%$ and $3.57 \%$ of the total sugars respectively). This can be rationalized by the presence of bark, which contains high levels of pectins and phenolics, lignin and tannins being recovered as acid-insoluble material using the Klason lignin method. According to Han et al. (2013), willow RSC stem and bark contain 70\% and $46 \%$ of polysaccharides respectively, bark retaining high content of lignin $(24.1 \%)$, water extracts $(24.7 \%)$ and aceton extracts $(5.1 \%)$. 


\begin{tabular}{|l|l|}
\hline \multicolumn{2}{|c|}{3} \\
\hline $\begin{array}{l}\text { Table 1 - Composition of willow } \\
\text { and trace element content } \\
\left(\mathrm{mg.kg}^{-1}\right)\end{array}$ \\
\hline \\
Klason lignin $^{\mathrm{a}}$ & $37.4 \%$ \\
Cellulose $^{\mathrm{a}}$ & $43.2 \%$ \\
Hemicellulose $^{\mathrm{a}}$ & $16.0 \%$ \\
Extracts $^{\mathrm{a}}$ & $7.75 \%$ \\
Zn $^{\mathrm{b}}$ & $223.3 \pm 12.0$ \\
$\mathrm{Mn}^{\mathrm{b}}$ & $25.8 \pm 1.9$ \\
$\mathrm{Cd}^{\mathrm{b}}$ & $<0.1$ \\
\hline
\end{tabular}

${ }^{\mathrm{a}} \%$ of dry wood. ${ }^{\mathrm{b}} \mathrm{mg} \cdot \mathrm{kg}^{-1}$ determined ICP-AES

Willow is described to have a high biomass production and is one of the trees that accumulates the most TE but at concentrations much lower than those found in hyperaccumulator plants (Syc et al., 2012, Migeon et al., 2009, Xu et al., 2018). Significantly lower TE concentrations were found in the stem compared with the leaves (Migeon et al., 2009). The dominant TE concentrations in the studied willow SRC with bark samples of this work is given in Table 1.

Steam explosion pretreatment performed on $\mathrm{H}_{2} \mathrm{SO}_{4}$ impregnated milled willow wood has been reported in a previous paper (Pan, 2008). The most favorable SE conditions regarding the sugar yields were $200{ }^{\circ} \mathrm{C}$ for 4 or 8 min using dilute acid presoaking $(0.25 \%$ and $0.50 \%$ sulfuric acid w/w). The condition sets used in the present study were selected considering these previously described results focusing on sugars yields but also, starting from a TEenriched wood, considering the TE extractability in the water effluent. In this context, higher sulfuric acid concentrations were investigated in our study $(0.9 \%$ and $2 \% \mathrm{w} / \mathrm{w})$ for promoting the TE extraction in the water effluents. 
1 The chemical compositions of the pulp after SE treatment of willow according to

2 experimental conditions are given in Table 2. Fig.1 provides the effect of the combined

3 severity ( $\log \mathrm{Cs})$ on the pulp yield whereas the glucose and xylose contents in the pulp are

4 shown in Fig. 2. As seen in Fig. 1, an increase in severity leads to the solubilization of an

5 increasing amount of the initial biomass. As expected, it appears from Fig. 2 that the mass

6 loss was primarily due to the hemicelluloses solubilization (or degradation), resulting in a

7 decreasing of the xylan content. In agreement with the literature (Simangunsong et al., 2018),

8 an increasing proportion of xylan with the severity of the treatment was extracted from the

9 solid pulp and recovered in the aqueous effluent producing a glucan-rich pulp. Using harsh

conditions $\left(220{ }^{\circ} \mathrm{C}, 8 \mathrm{~min}, 2 \% \mathrm{H}_{2} \mathrm{SO}_{4}\right)$, a cellulose rich pulp containing approximately $97 \%$

of glucose among the total sugars in the treated wood was produced (Fig. 2).

Table 2 - Experimental conditions for the SE pretreatment. Compositions of the solid residues after pretreatment.

Glc: glucose, Xyl : xylose.

\begin{tabular}{|c|c|c|c|c|c|c|c|c|}
\hline $\mathrm{T}^{\circ} \mathrm{C}$ & $\begin{array}{l}\mathrm{T} \\
(\mathrm{mi} \\
\mathrm{n})\end{array}$ & $\begin{array}{l}\mathrm{PS}^{\mathrm{a}} \\
\%\end{array}$ & $\begin{array}{c}\text { Log } \\
\text { Cs }\end{array}$ & $\begin{array}{c}\mathrm{Glc}^{\mathrm{a}} \\
\%\end{array}$ & $\mathrm{Xyl}^{\mathrm{b}} \%$ & $\begin{array}{l}\text { Other } \\
\text { sugars }^{\mathrm{b}} \%\end{array}$ & $\mathrm{Zn}^{\mathrm{c}}$ & $\mathrm{Mn}^{\mathrm{c}}$ \\
\hline 180 & 2 & 0.9 & 0.0 & $\begin{array}{c}70.4 \\
9\end{array}$ & 22.06 & 7.45 & $\begin{array}{l}55.06 \\
\pm 3,43\end{array}$ & $\begin{array}{c}48.29 \pm 1 \\
3,13\end{array}$ \\
\hline 180 & 5 & 0.9 & 0.4 & $\begin{array}{c}79.3 \\
1\end{array}$ & 15.57 & 5.11 & $\begin{array}{l}38.97 \\
\pm 2,61\end{array}$ & $\begin{array}{c}37.13 \pm 1 \\
, 13\end{array}$ \\
\hline 180 & 8 & 0.9 & 0.6 & $\begin{array}{c}80.3 \\
9\end{array}$ & 15.50 & 4.11 & $\begin{array}{l}30.43 \\
\pm 1,48\end{array}$ & $\begin{array}{l}40.83 \\
\pm 1,14\end{array}$ \\
\hline 200 & 2 & 0.9 & 0.5 & $\begin{array}{c}81.9 \\
7\end{array}$ & 13.93 & 4.10 & $\begin{array}{l}34.00 \\
\pm 4,40\end{array}$ & $\begin{array}{c}22.92 \pm \\
9,85\end{array}$ \\
\hline 200 & 5 & 0.9 & 0.9 & $\begin{array}{c}82.5 \\
5\end{array}$ & 12.92 & 4.54 & $\begin{array}{l}26.74 \\
\pm 2,09\end{array}$ & $\begin{array}{l}34.75 \\
\pm 0,98\end{array}$ \\
\hline 200 & 8 & 0.9 & 1.1 & $\begin{array}{c}87.4 \\
0\end{array}$ & 9.59 & 3.01 & $\begin{array}{l}30.24 \\
\pm 0,58\end{array}$ & $\begin{array}{l}31.32 \\
\pm 0,07\end{array}$ \\
\hline 220 & 2 & 0.9 & 1.1 & $\begin{array}{c}87.3 \\
2\end{array}$ & 9.17 & 3.51 & $\begin{array}{l}26.74 \\
\pm 2,09\end{array}$ & $\begin{array}{l}34.75 \\
\pm 0,98\end{array}$ \\
\hline
\end{tabular}




\begin{tabular}{|c|c|c|c|c|c|c|c|c|}
\hline 220 & 5 & 0.9 & 1.5 & 92.8 & 5.04 & 2.11 & $\begin{array}{l}28.43 \\
\pm 5,13\end{array}$ & $\begin{array}{l}27.97 \\
\pm 3,39\end{array}$ \\
\hline 220 & 8 & 0.9 & 1.7 & $\begin{array}{c}94.1 \\
8\end{array}$ & 4.36 & 146 & $\begin{array}{l}30.13 \\
\pm 0,57\end{array}$ & $\begin{array}{l}52.89 \\
\pm 0,51\end{array}$ \\
\hline 180 & 2 & 2 & 0.3 & $\begin{array}{c}72.9 \\
4\end{array}$ & 20.33 & 6.73 & $\begin{array}{c}38.97 \pm \\
2.61\end{array}$ & $\begin{array}{c}37.13 \pm 1 \\
.13\end{array}$ \\
\hline 180 & 5 & 2 & 0.7 & $\begin{array}{c}78.1 \\
6\end{array}$ & 16.91 & 4.93 & $\begin{array}{c}34.00 \pm \\
4.40\end{array}$ & $\begin{array}{c}34.37 \pm 0 \\
.09\end{array}$ \\
\hline 180 & 8 & 2 & 0.9 & $\begin{array}{c}83.6 \\
7\end{array}$ & 13.18 & 3.14 & $\begin{array}{c}30.24 \pm \\
0.85\end{array}$ & $\begin{array}{c}31.32 \pm 0 \\
.07\end{array}$ \\
\hline 200 & 2 & 2 & 0.8 & $\begin{array}{c}81.9 \\
4\end{array}$ & 13.45 & 4.62 & $\begin{array}{c}28.43 \pm \\
5.12\end{array}$ & $\begin{array}{c}27.97 \pm 3 \\
.39\end{array}$ \\
\hline 200 & 5 & 2 & 1.2 & $\begin{array}{c}89.3 \\
8\end{array}$ & 8.15 & 2.47 & $\begin{array}{c}24.16 \pm \\
1.49\end{array}$ & $\begin{array}{c}2378 \pm 1 \\
84\end{array}$ \\
\hline 200 & 8 & 2 & 1.4 & $\begin{array}{c}93.4 \\
7\end{array}$ & 4.77 & 1.76 & $\begin{array}{c}21.52 \pm \\
3.75\end{array}$ & $\begin{array}{c}24.49 \pm 1 \\
.48\end{array}$ \\
\hline 220 & 2 & 2 & 1.4 & $\begin{array}{c}93.5 \\
3\end{array}$ & 4.68 & 1.79 & $\begin{array}{c}24.11 \pm \\
1.46\end{array}$ & $\begin{array}{c}22.25 \pm 0 \\
.49\end{array}$ \\
\hline 220 & 5 & 2 & 1.8 & $\begin{array}{c}93.5 \\
6\end{array}$ & 4.50 & 1.95 & $\begin{array}{c}16.07 \pm \\
2.22\end{array}$ & $\begin{array}{c}17.15 \pm 1 \\
.49\end{array}$ \\
\hline 220 & 8 & 2 & 2.0 & $\begin{array}{c}97.3 \\
2\end{array}$ & 2.31 & 0.37 & $\begin{array}{c}14.84 \pm \\
2.97\end{array}$ & $\begin{array}{c}16.25 \pm 1 \\
.36\end{array}$ \\
\hline
\end{tabular}

${ }^{a}$ Concentration of $\mathrm{H}_{2} \mathrm{SO}_{4} \mathrm{w} / \mathrm{w}$ during the presoaking step. ${ }^{b} \% \mathrm{w} / \mathrm{w}$ based on the sugars content. ${ }^{c}$ mg.kg ${ }^{-1}$ determined ICP-AES presoaking conditions performed.

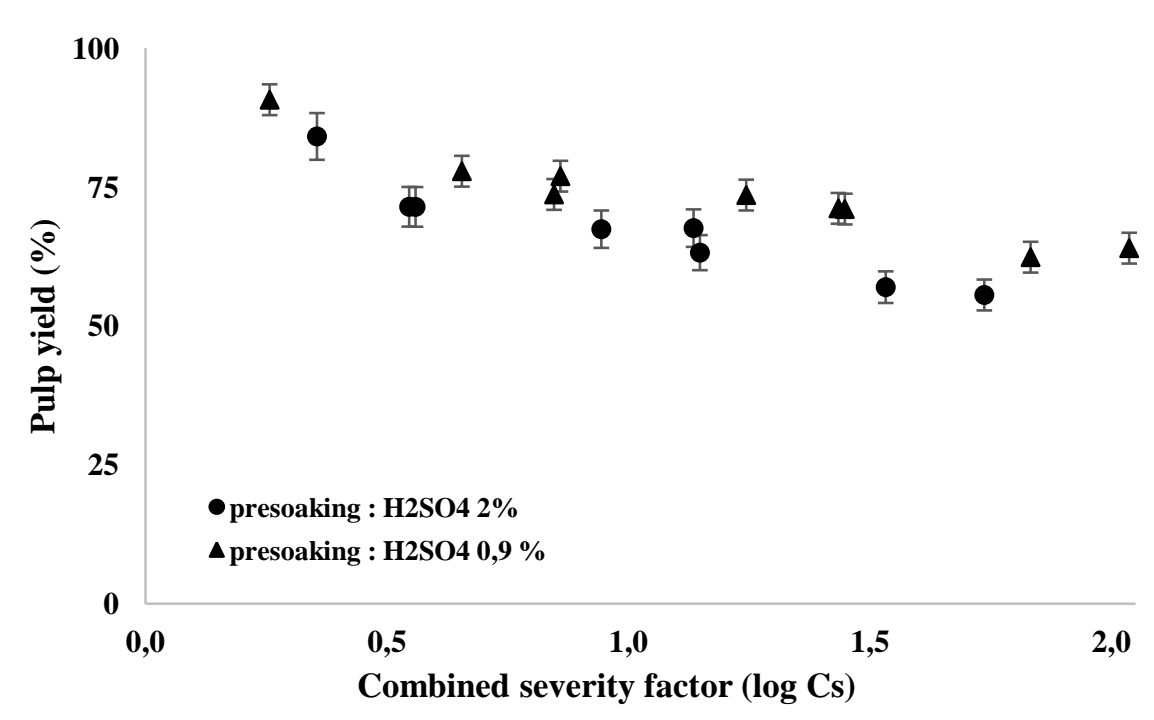


Fig.2. Glucan (A) and xylan (B) levels (\% based on the sugar contents) in the solid residues after SE as a function of the combined severity (Log Cs) for the two presoaking conditions.

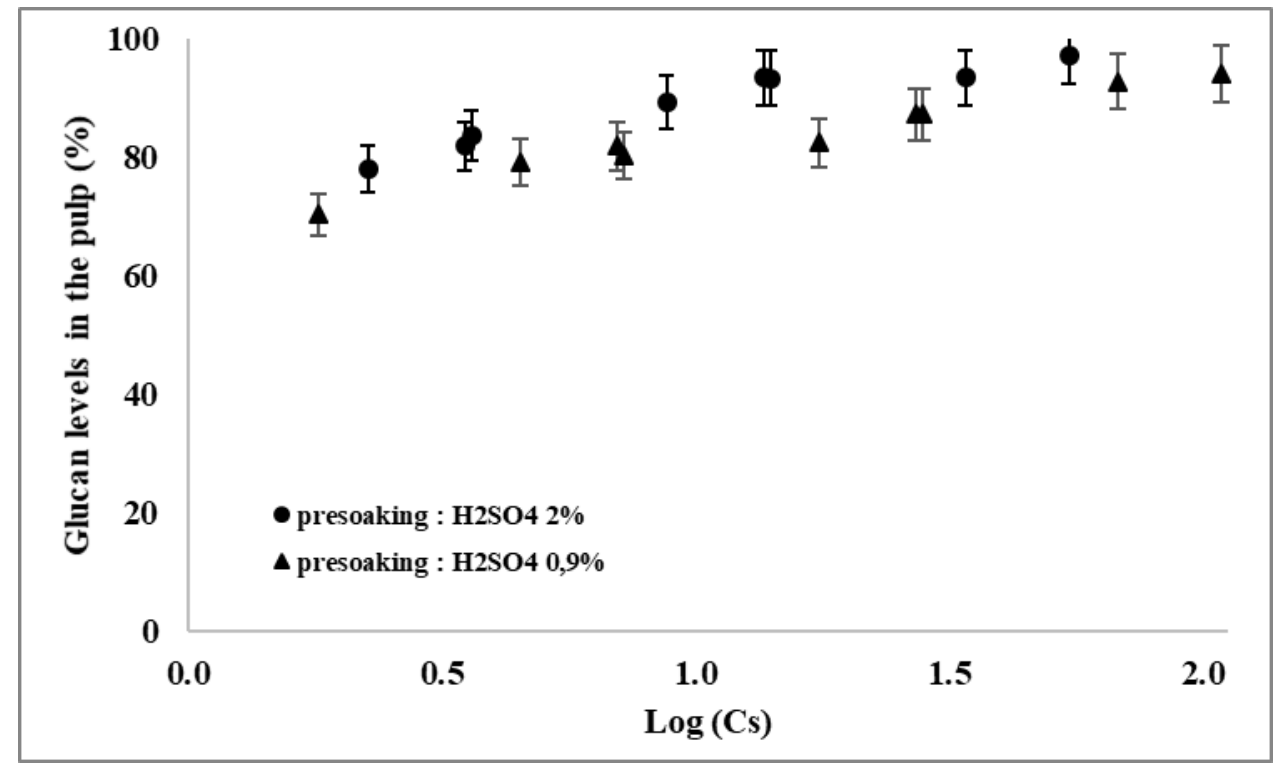

4

5

6

7

8

9

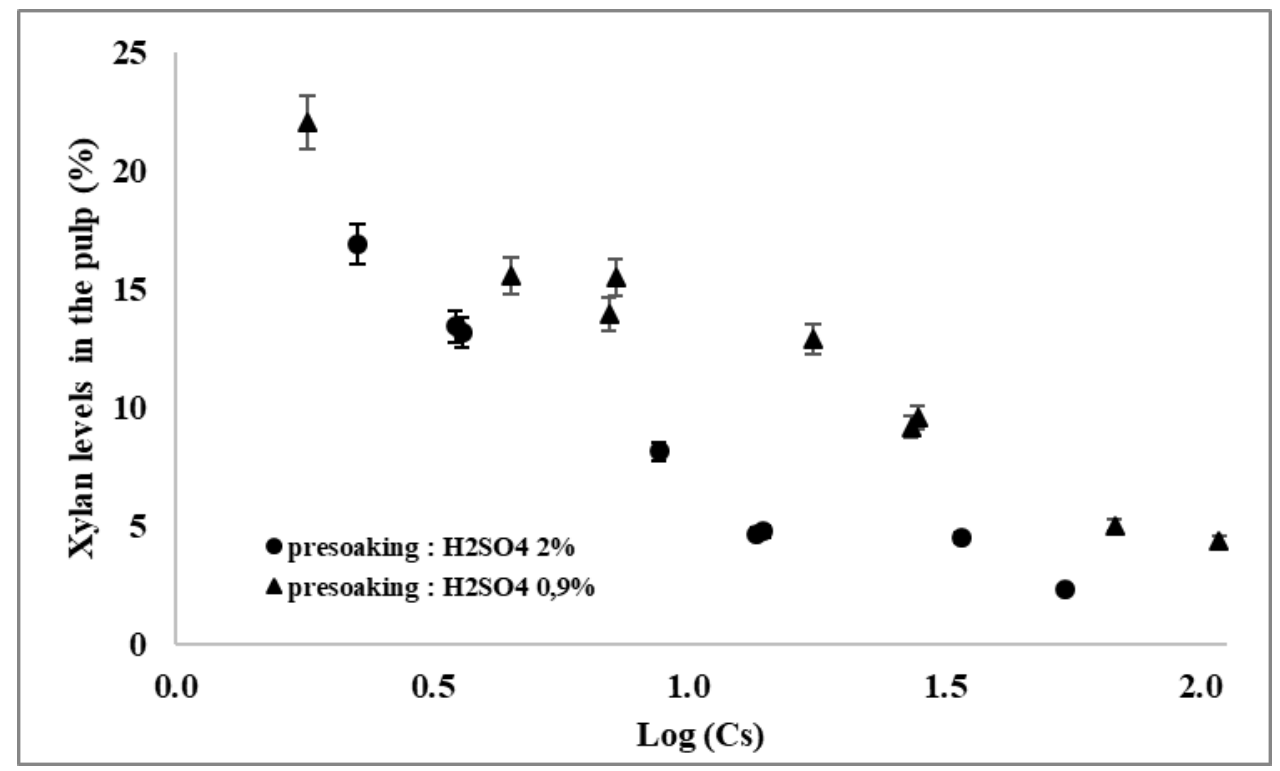

The influence of the SE severity on TE content $(\mathrm{Mn}$ and $\mathrm{Zn})$ remaining in the residual pulp is given in Fig. 3. It can be seen (Fig 3A and 3B) that the TE extraction was affected by the pre-

7 soaking conditions $\left(\mathrm{H}_{2} \mathrm{SO}_{4} \%\right)$. In agreement with previous papers regarding acid-catalyzed

pretreatment of TE-enriched biomass, an increase in the acid concentration and in residence

time of the treatment enhanced the TE extraction in the water effluent (Asad et al, 2017,

0 Sassner et al., 2007). The lignocellulosic matrix has been described to have affinity with

1 divalent metal ions, which may be bound primarily to non-cellulosic polysaccharide 
1

components (Asad et al, 2017). As a result, the acid-catalyzed removal of the hemicellulosic fraction during the steaming step of SE previously mentioned could partly explain the concomitant sugars and TE extraction in the liquid stream of the process. The results recently published starting from the same biomass and using dilute acid pretreatment (similar treatment but without explosive decompression), showed that an increase in temperature resulted in a decrease of the TE extraction from the pulp (Asad et al, 2017). Interestingly, an opposite trend was observed in the present study using SE, the higher the operating temperature, the higher the TE extraction in the water effluents. Indeed, using comparable conditions at $200^{\circ} \mathrm{C}$ and 5 min residence time, $\sim 37 \%$ of $\mathrm{Zn}$ was recovered in the pulp using dilute acid treatment compared to $\sim 21 \%$ for SE. In the SE process, the temperature is correlated to pressure which has a direct impact on the shearing forces applied to the lignocellulosic fibers during the explosive release. Pielhop et al. (2016) showed that increasing the pressure difference of the explosion led to more defibration and to smaller particle size, increasing the digestibility. As a result, at high operating temperature an extensive disruption of the fibrils during SE with a strong reduction of the particle size could increase the accessibility of the TE in the cell wall tissue facilitating their extraction in aqueous phase.

Fig. 3. Trace elements (expressed as percent of the total initial content of the raw material) recovery in the SE wood pulp vs combined severity.
A) Zinc
B) Manganese 

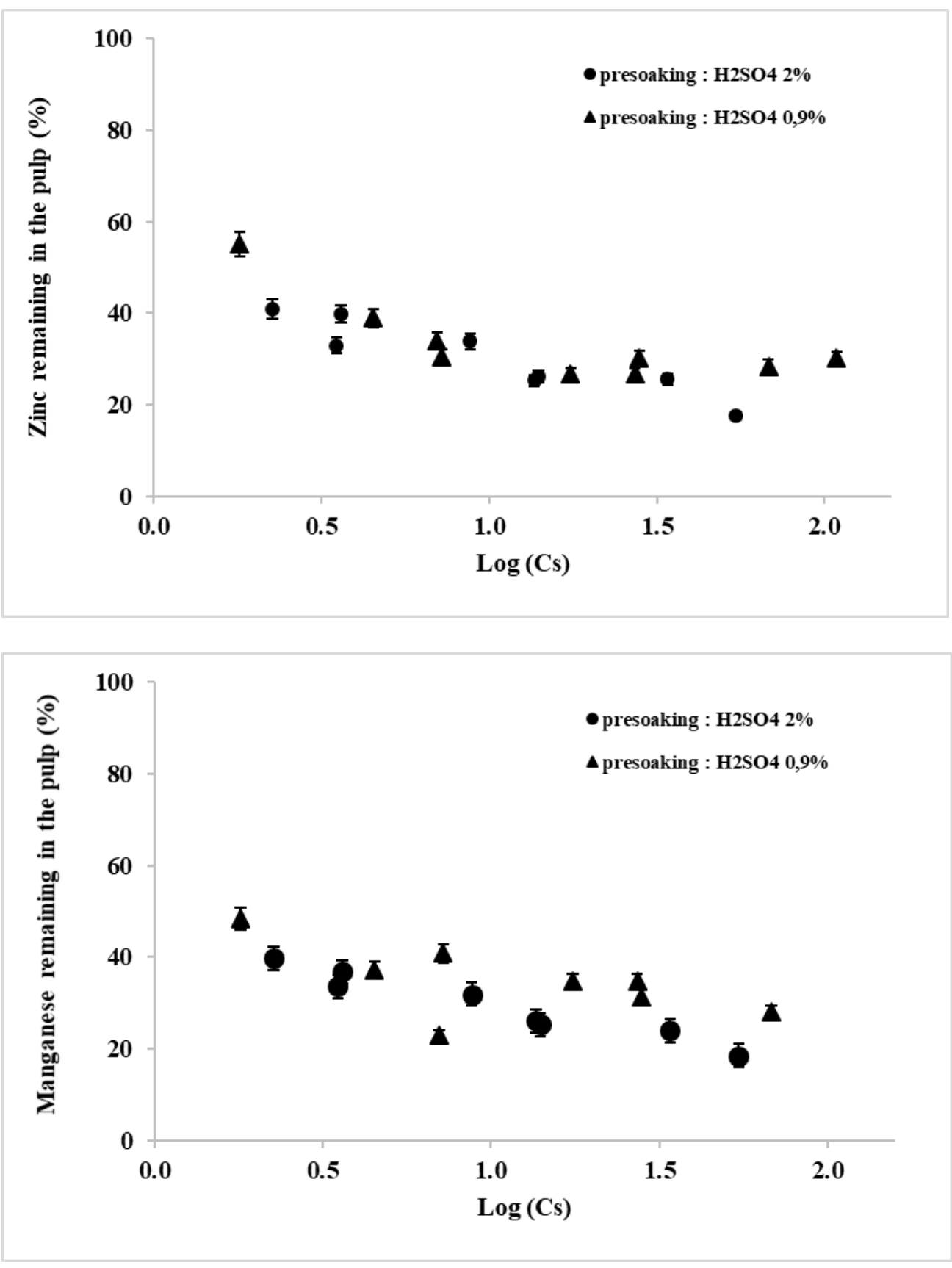

3 In a previous study performed on willow wood (Asad et al, 2017), we showed that in a basic

4 pretreatement, TE were mostly recovered in the pulp while in an organosolv pulping 30\% -

$540 \%$ of Mn and Zn were solvent-extracted. Syc et al. (2012) studied the composting of

6 willow contaminated with $\mathrm{Zn}$ and $\mathrm{Cd}$. According to these authors, $24-30 \%$ of the total $\mathrm{Zn}$

7 amount and $8-12 \%$ of the total $\mathrm{Cd}$ were leachable at weakly acid $\mathrm{pH}$ with strong effect of

8 the $\mathrm{pH}$, the more acidic medium, the higher Cd extraction in water. Using a SE pretreatment

9 performed at $220{ }^{\circ} \mathrm{C}$ during $5 \mathrm{~min}$ after a $2 \%$ w/w $\mathrm{H}_{2} \mathrm{SO}_{4}$ impregnation, $~ 80 \%$ of $\mathrm{Zn}$ and 
1 Mn were removed from wood and recovered in the water effluent. Thus, steam explosion

2 appears to be an efficient method for the water extraction of TE from phytoremediation wood.

3 In this context, TE removal from the water stream (water condensed in the discharge tank of

4 the SE facility) has to be considered carefully to minimize TE dissemination and negative

5 environmental impacts of the whole process. In the literature, efficient TE adsorbents

6 exhibiting a high adsorption efficiency and short equilibrium time have been described via

7 coordination and ion exchange. Graphene, zeolite, chitosane derivatives have been

8 successfully used to remove heavy metal ions from wastewater (Zhang et al., 2018). In the

9 present study, a phosphorylated cellulosic material (Belosinschi et al., 2017) was

Fig. 4. $\mathrm{Zn}$ and $\mathrm{Mn}$ concentrations before and after detoxification by resin treatment $\left(0.2 \%\right.$ of resin $\left.\mathrm{w} / \mathrm{w}, 1 \mathrm{hr}, 20^{\circ} \mathrm{C}\right)$ 


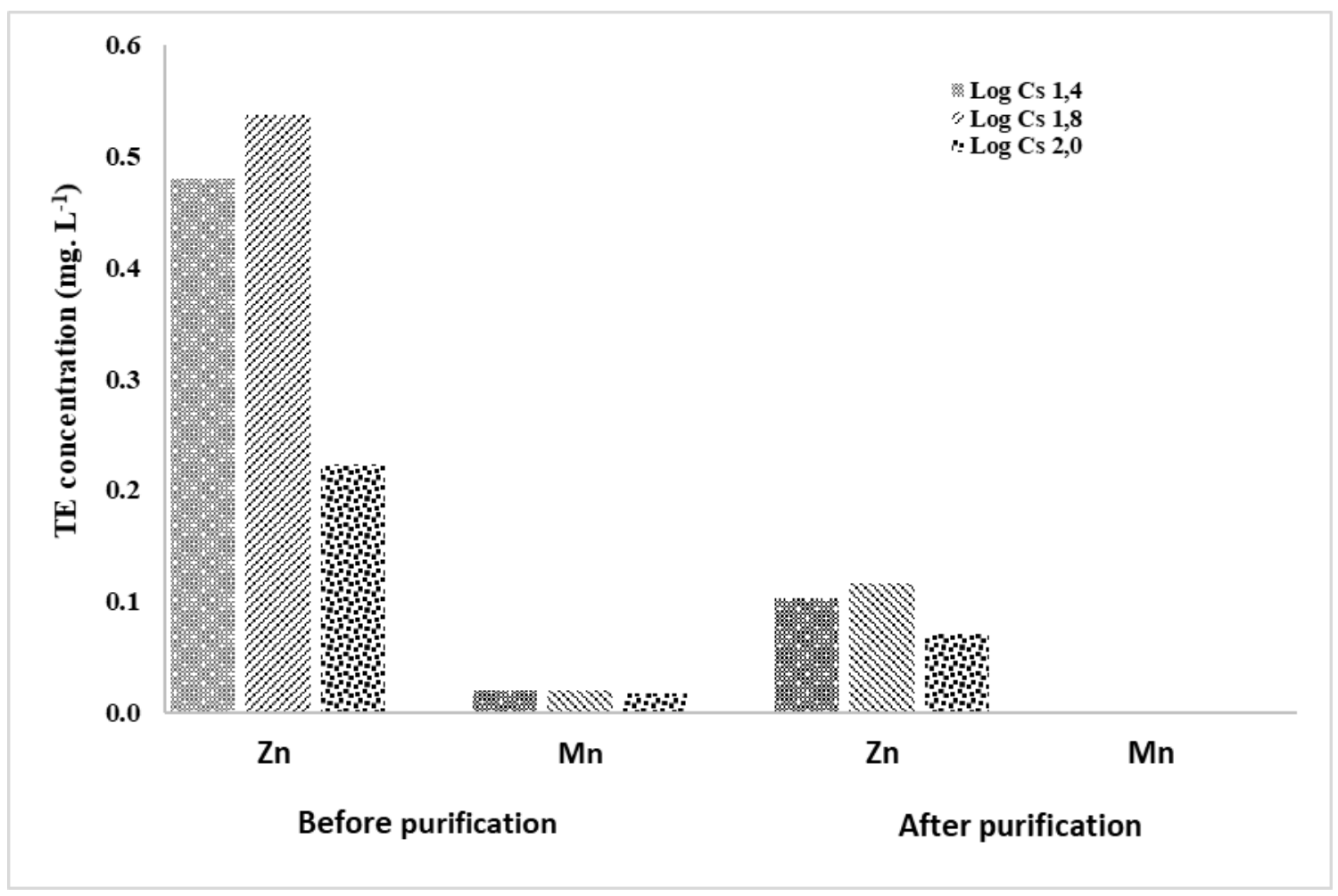

2 The results of enzymatic saccharification of phytoremediation SRC willow wood pretreated by steam explosion performed during $5 \mathrm{~min}$ at three different temperatures $\left(180{ }^{\circ} \mathrm{C}, 200{ }^{\circ} \mathrm{C}\right.$ and $220^{\circ} \mathrm{C}$ ), corresponding respectively to combined severity factors of $0.6,1.2,1.8$, are shown in Figure 5A. A cellulose-to-glucose conversion of $\sim 80 \%$ was obtained after $75 \mathrm{hr}$ of incubation of the pulp obtained after a steam explosion treatment performed at $180{ }^{\circ} \mathrm{C}$. This value is close to that previously reported starting from pretreated willow pulps (Huijgen et al., 2011). The presence of TE and the relatively high Klason lignin content in willow wood do not negatively impact the enzymatic hydrolysability of lignocellulosic substrate. At higher pretreatment temperatures $\left(200^{\circ} \mathrm{C}\right.$ and $\left.220^{\circ} \mathrm{C}\right)$ slightly lower cellulose-to-glucose conversions were observed $(\sim 75 \%)$. Using these more severe conditions, the degradation reactions gave rise to furfural and HMF (Sassner et al., 2007), which inhibited the enzymatic digestion. The sugar solutions resulting from the enzymatic hydrolysis were fermented using Saccharomyces cerevisiae to investigate their fermentability. Figure 5B shows ethanol yields after $12 \mathrm{hr}$ of fermentation of the enzymatic hydrolysates derived from SE-pulps containing respectively Zn (88 mg. $\left.\mathrm{kg}^{-1}, 87 \mathrm{mg} . \mathrm{kg}^{-1}, 71 \mathrm{mg} . \mathrm{kg}^{-1}\right)$ and $\mathrm{Mn}\left(11 \mathrm{mg} . \mathrm{kg}^{-1}, 9 \mathrm{mg} . \mathrm{kg}^{-1}, 8\right.$ 
$\left.1 \mathrm{mg} . \mathrm{kg}^{-1}\right)$. No significant difference was observed in the ethanol yields $(\sim 65 \%)$

2 demonstrating the fermentability of the liquors. It has been described that TE can exhibit a

3 toxic effect toward microorganisms and decrease the fermentation efficiency (Yang et al,

4 2017, Gomez et al., 2002). However, Saccharomyces cerevisiae is recognized to exhibit a

5 relatively high tolerance to inhibitors and the toxicity was primarily reported in the presence

6 of $\mathrm{Cd}, \mathrm{Hg}$ and $\mathrm{Pb}$ (Buijs et al., 2013). In the present study, the relatively low concentrations of

$7 \quad \mathrm{TE}\left(<2 \mathrm{mg} \cdot \mathrm{L}^{-1}\right)$ had no significant impact on the yeast productivity.

Fig. 5. Enzymatic saccharification of phytoremediation SRC willow wood.

A) Cellulose-to-glucose conversion (\%) at different points during enzymatic hydrolysis of willow1 (W1) SE pulps.

B) Ethanol yield after $12 \mathrm{hr}$ of fermentation

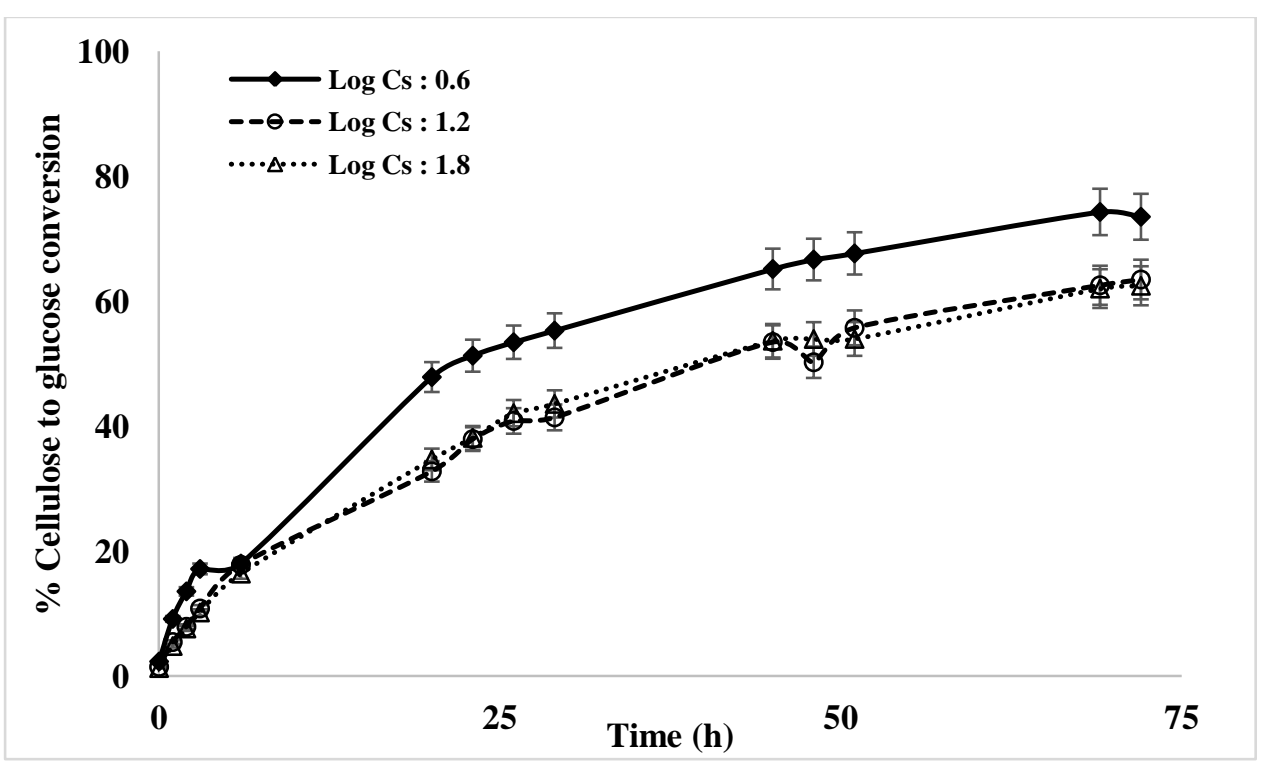




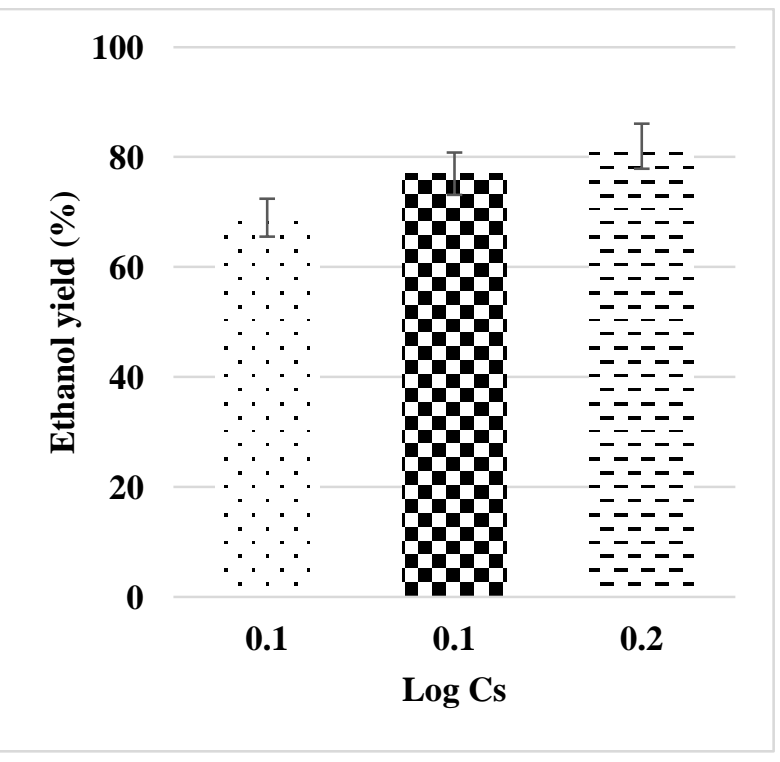

3

\section{Conclusion}

In this study we have examined the SE pretreatment of willow grown on phytomanaged soils and contaminated with moderate to low levels of TE ( $\mathrm{Zn}, \mathrm{Mn})$ for bioethanol production. SE was evaluated and optimized for the decontamination of TE from woody biomass and the recovery of heavy metals in the water effluents of the process. It has been shown that the explosive decompression step in the SE process increased the extractability of TE from the cell wall tissue. The enzymatic saccharification of the resulting cellulosic pulps followed by yeast fermentation have been examined and no significant inhibitory effect of the residual TE on the biocatalysts was observed. Thus we have demonstrated the possibility to combine phytomanagement approaches for decontamination of polluted soils with utilizations of the biomass produced such as bioethanol production.

\section{Acknowledgements}

The authors gratefully acknowledge the financial supports of the Conseil Régional de Lorraine through the LORVER project, the ANR through the PHYTOCHEM project (ANR 13-CD2I-0005-01) and the European Commission through FEDER funds. LERMAB is 
supported by the French National Research Agency through the Laboratory of Excellence ARBRE (ANR-12- LABXARBRE-01).

D. Belosinschi and F. Brouillette are warmly thanked for the resin samples.

\section{References}

Asad, M., Menana, Z., Ziegler-Devin, I., Bert, V., Chalot, M., Herzig, R., Mench, M., Brosse, N. (2017). Pretreatment of trace element-enriched biomasses grown on phytomanaged soils for bioethanol production. Ind. Crops Prod. 107: 63-72.

Belosinschi, D., Brouillette, F., Shi, Y., Paradis, J., Doucet, J. (2017). Phosphorylated lignocellulosic fibers, uses and processes of preparation thereof. PCT Int. Appl. WO 2017214719 A1 20171221.

Buijs, N.A., Siewers, V., Nielsen, J. (2013). Advanced biofuel production by the yeast Saccharomyces cerevisiae. Curr. Opin. Chem. Biol. 17: 3, 480-488.

Chalot, M., Blaudez, D., Rogaume, Y., Provent, A.S., Pascual, C. (2012). Fate of trace elements during the combustion of phytoremediation wood. Environ. Sci. Technol. 46: $13361-13369$.

Chum, H.L., Johnson, D.K., Black, S.K., Overend, R. P. (1990). Pretreatment catalyst effects and the combined severity parameter. Applied Biochemistry and Biotechnology 245 : 1-14. DOI: $10.1007 /$ bf02920229.

Delplanque, M., Collet, S., Del Gratta, F., Schnuriger, B., Gaucher, R., Robinson, B., Bert, V. (2013). Combustion of Salix used for phytoextraction: The fate of metals and viability of the processes. Biomass Bioener. 49: 160-170.

Gallego, J.R., Esquinas, N., Rodriguez-Valdes, E., Menendez-Aguado, J.M., Sierra, C. (2015). Comprehensive waste characterization and organic pollution co-occurrence in a Hg and As mining and metallurgy brownfield. J. Hazard. Mat. 300: 561-571. 
1 Gomes, D.S., Fragoso, L.C., Riger, C.J., Panek, A.D., Eleutherio, E.C.A. (2002). Regulation of cadmium uptake by Saccharomyces cerevisiae. Biochim. Biophys. Acta, Gen. Subj. 1573: 1, 21-25.

Gomez, H.I. (2012). Phytoremediation for bioenergy: challenges and opportunities. Environ. Technol. 1-8.

Han, S.H., Cho, D.H., Kim, Y.H., Shinc, S.-J. (2013). Biobutanol production from 2-year-old willow biomass by acid hydrolysis and acetone-butanol-ethanol fermentation. Energy. 61: 13-17

Huijgen, W.J.J., Smit, A.T., Reith, J.H., den Uil, H. (2011). Catalytic organosolv fractionation of willow wood and wheat straw as pretreatment for enzymatic cellulose hydrolysis, J. Chem. Technol. Biotechnol. 86: 1428-1438.

Jacquet, N., Maniet, G., Vanderghem, C., Delvigne, F., Richel, A. (2015). Application of Steam Explosion as Pretreatment on Lignocellulosic Material. A Review, Ind. Eng. Chem. Res. 54: 2593-2598.

Kidd, P., Mench, M., Álvarez-López, V., Bert, V., Dimitriou, I., Friesl-Hanl, W., Herzig, R., Janssen, J.O., Kolbas, A., Müller, I., Neu, S., Renella, G., Ruttens, A., Vangronsveld, J., Puschenreiter, M. (2015). Agronomic practices for improving gentle remediation of trace-element-contaminated soils. Int. J. Phytorem.17: 1005-1037.

Migeon, A., Richaud, P., Guinet, F., Chalot, M., Blaudez, D. (2009). Metal accumulation by woody species on contaminated sites in the North of France. Water Air Soil Pollut. 204: 89-101.

Medina, J., Monreal, C., Barea, J.M., Arriagada, C., Borie, F., Cornejo, P. (2015). Crop residue stabilization and application to agricultural and degraded soils: A review. Waste Manage. 42: 41-54. 
1 Nagendran, R., Selvam, A., Kurian, J., Chart, C. (2006). Phytoremediation and rehabilitation of municipal solid waste landfills and dumpsites: A brief review. Waste Manage. 26: $1357-1369$

Pan, X. (2008). Role of functional group in lignin inhibition of enzymatic hydrolysis of cellulose to glucose. J. Biobased Mat. and Bioenerg. 2: 25-32.

Pielhop, T., Amgarten, J., Rudolf von Rohr, P., Studer, M.H. (2016). Steam explosion pretreatment of softwood: the effect of the explosive decompression on enzymatic digestibility. Biotechnol Biofuels 9:152-164.

Sassner, P., Maartensson, C.-G., Galbe, M., Zacchi, G. (2007). Steam pretreatment of $\mathrm{H}_{2} \mathrm{SO}_{4}-$ impregnated Salix for the production of bioethanol, Bioresour. Technol. 99(1): 137145.

Sauvageon, T., Lavoie, J.-M., Segovia, C., Brosse, N. (2018). Toward the cottonisation of hemp fibers by steam explosion - Part 1 - Defibration and morphological characterization. Textile Research Journal 88 (9): 1047-1055

Simangunsong, E., Ziegler-Devin, I., Chrusciel, L., Girods, P., Wistara, N.J., Brosse, N. (2018). Steam explosion of beech wood. Effect of the particle size on the xylans recovery. Waste and Biomass Valorization https://doi.org/10.1007/s12649-018-0522$\underline{4}$

Söderstroem, J., Pilcher, L., Galbe, M., Zacchi, G. (2003). Two-step steam pretreatment of softwood by dilute $\mathrm{H}_{2} \mathrm{SO}_{4}$ impregnation for ethanol production. Biomass and Bioener. 24: 475-486.

Suer, P., Andersson-Skold, Y. (2011). Biofuel or excavation? - Life cycle assessment (LCA) of soil remediation options. Biomass Bioener. 35: 969-981. 
Syc, M., Pohorely, M., Kamenikova, P., Habart, J., Svoboda, K., Puncochar, M. (2012). Willow trees from heavy metals phytoextraction as energy. Biomass Bioener. 37: 106-113.

Vervaeke, P., Tack, F.M.G., Navez, F., Martin, J., Verloo, M.G., Lust, N. (2006). Fate of heavy metals during fixed bed downdraft gasification of willow wood harvest from contaminated sites. Biomass Bioener. 30: 58-65.

Witters, N., Mendelsohn, R., Van Passel, S., Van Slycken, S., Weyens, N., Schreurs, E., Meers, E., Tack, F., Vanheusden, B., Vangronsveld, J. (2012). Phytoremediation, a sustainable remediation technology? II: Economic assessment of $\mathrm{CO}_{2}$ abatement through the use of phytoremediation crops for renewable energy production. Biomass Bioener. 39: 470-477.

Xu, H., Yu, C., Xia, X., Li, M., Li, H., Wang, Y., Wang, S., Wang, C., Ma, Y., Zhou, G. (2018). Comparative transcriptome analysis of duckweed (Landoltia punctata) in response to cadmium provides insights into molecular mechanisms underlying hyperaccumulation, Chemosphere 190: 154-165.

Xue, K., van Nostrand J.D., Vangronsveld, N., Witters, N., Janssen, J.O.; Kumpiene, J., Siebielec, G., Galazka, R., Giagnoni, L., Arenella, M., Zhou, J.-Z., Renella, G. (2015). Management with willow short rotation coppice increase the functional gene diversity and functional activity of a heavy metal polluted soil. Chemosphere 138: 469-477.

Yang, C.-E., Chu, I.M., Wei, Y.-H., Tsai, S.-L. (2017). Surface display of synthetic phytochelatins on Saccharomyces cerevisiae for enhanced ethanol production in heavy metal-contaminated substrates. Bioresour. Technol. 245: 1455-1460. 
1 Zhang, C.-Z., Chen, B., Bai, Y., Xie, J. (2018). A new functionalized reduced graphene oxide adsorbent for removing heavy metal ions in water via coordination and ion exchange.

3 Separation science and Technology 53(18): 2896-2905.

4 